\title{
Biodiversity and ecology of potential vectors (Insecta: Hemiptera: Auchenorryncha) of Xylella fastidiosa Wells et al. in coffee plants of Puerto Rico ${ }^{1,2}$
}

\author{
Yobana Mariño-Cárdenas ${ }^{3}$, Mildred Zapata ${ }^{4}$, \\ Brent V. Brodbeck ${ }^{5}$, Stuart McKamey ${ }^{6}$ and Peter C. Andersen ${ }^{7}$
}

J. Agric. Univ. P.R. 94(1-2):147-164 (2010)

\begin{abstract}
$X y / e l l a$ fastidiosa $(\mathrm{Xf})$ is a xylem-limited bacterium that is the causal agent of coffee leaf scorch (CLS) in Central America. The purpose of this research was to survey potential vectors of Xf in plantings of coffee, Coffea arabica L., in Puerto Rico. These surveys were conducted from June to November 2006 on four farms, located in the municipalities of Yauco, Juana Díaz and Adjuntas. Insects were collected at each site at 15-day intervals. The 7,423 individuals collected belonged to five families and 12 species. Cicadellidae was the primary family in both number of species and number of individuals. Indexes of dominance, abundance, frequency and constancy showed Agallia putchra, Apogonalia imitatrix, Caribovia coffeacola and Hortensia similis to be the predominant species. Indexes also showed significant differences among locations, with higher diversity and equitability on Yauco farms, and higher dominance in Adjuntas. Of the four dominant species, Apogonalia imitatrix, C. coffeacola and $H$. similis are all xylem fluid feeders, and thus may
\end{abstract}

${ }^{1}$ Manuscript submitted to the Editorial Board 18 December 2008.

${ }^{2}$ This research was financed by project ZTS-16 (USDA/CSREES) and TSTAR \#3413515669. The authors wish to thank Dr. Ángel González and Prof. Edwin Abreu for their excellent comments on sampling and Dr. Thomas Henry for his comments on the manuscript; Miguel Arango and Neis Martínez for assistance with the statistical analysis and Rosario Gaud, Alvaro Serrano, Wigmar González, Manuel Santana, and Diego Viteri for their collaboration in field work for this research.

${ }^{3}$ Former Graduate Student, Department of Crop Protection, College of Agricultural Sciences, University of Puerto Rico-Mayagüez, PR.

${ }^{4}$ Professor and Researcher, Department of Crops and Agroenvironmental Sciences, College of Agricultural Sciences, University of Puerto Rico-Mayagüez. PO Box 9000, Mayagüez, PR 00681.

${ }^{5}$ Senior Biological Scientist, North Florida Research and Education Center, University of Florida, Quincy, FL.

${ }^{6}$ Research Entomologist, Systematic Entomology Laboratory ARS, U.S. Department of Agriculture c/o National Museum of Natural History, Smithsonian Institution, Washington, DC., USA

TProfessor of Horticulture, North Florida Research and Education Center, University of Florida, Quincy, FL. 
be potential vectors of Xf. Apogonalia imitatrix represents the first report of the species for Puerto Rico.

Key words: Agallia, Apogonalia, Caribovia, Hortensia

\title{
RESUMEN
}

Biodiversidad y ecologia de vectores potenciales (Insecta: Hemiptera: Auchenorryncha) de Xylella fastidiosa Wells et al. en los cafetos en Puerto Rico

\begin{abstract}
Xylella fastidiosa (Xf) es una bacteria limitada al xilema y es el agente causal de la enfermedad conocida como el encorchado de la hoja del café (CLS) en América Central. El objetivo de esta investigación fue determinar insectos vectores potenciales de Xf en plantaciones de café, Coffea arabica L., de Puerto Rico. Los catastros se realizaron de junio a noviembre de 2006 en cuatro fincas localizadas en los municipios de Yauco, Juana Díaz y Adjuntas. La colección de insectos para cada sitio se realizó cada 15 días. Se recolectaron 7,423 individuos distribuidos en cinco familias y 12 especies. La familia Cicadellidae fue la dominante en número de especies e individuos. Los índices de dominancia, abundancia, frecuencia y constancia determinaron a Agallia pulchra, Apogonalia imitatrix, Caribovia coffeacola y Hortensia similis como las especies dominantes. Los índices de diversidad mostraron diferencias significativas entre localidades. Los valores más altos de diversidad y equidad de abundancia fueron para las fincas de Yauco y el de la dominancia para Adjuntas. De las cuatro especies dominantes Apogonalia imitatrix, $C$. coffeacola y $H$. similis correspondieron a insectos que se alimentan del xilema; por tanto, son considerados vectores potenciales de Xf. Apogonalia imitatrix representa el primer informe de la especie para Puerto Rico.
\end{abstract}

Palabras clave: Agallia, Apogonalia, Caribovia, Hortensia, café

\section{INTRODUCTION}

The gram negative bacterium Xylella fastidiosa Wells et al. (1987) (Xf) is responsible for diseases that cause economic loss in many agricultural crops. Xylella fastidiosa is a xylem-limited bacterium that can also live in symptomless hosts that serve as a source of inoculum (Purcell and Hopkins, 1996; Newman et al., 2004). This bacterium colonizes the xylem, interrupting the movement of water and minerals; xylem vessels may become occluded by dense colonization. High frequencies of blocked vessels result in symptom development and may result in plant mortality in some host plant species (Blake et al., 2004). This bacterium is reported as the causal agent of "coffee leaf scorch" (CLS), which is a major limitation for coffee (Coffea arabica L.) production in Costa Rica and Brazil (Li et al., 2001 ) and is a major threat to Puerto Rican coffee, which is the second most important crop in the mountainous region (Monroig, 2007).

Xylella fastidiosa is transmitted only by xylem-feeding insects including Cicadellidae: Cicadellinae (sharpshooter leafhoppers) and Cercopidae (froghoppers and spittlebugs) (Hopkins, 1989; Lopes, 1996; Almeida and Purcell, 2003; Redak et al, 2004; Brodbeck et al., 2006). As insects that ingest xylem fluid, all Cicadellinae and Cecropidae are po- 
tential vectors of the bacterium; all Cicadellinae and Cecropidae tested to date have shown the capacity to vector Xf (Almeida and Purcell, 2003; Redak et al., 2004). In areas where Xf causes economic losses, insects of the subfamily Cicadellinae have repeatedly been shown to be the primary vectors (Redak et al., 2004). The USDA checklist records only six species of Cicadellinae previously reported in Puerto Rico (http://www.sel.barc.usda.gov/selhome/leafhoppers/mckpaper.htm).

However, four of these species have been reported in plantings of citrus and coffee: Caribovia coffeacola (Dozier), Caribovia coffeaphila (Young), Hortensia similis (Walker), and Apogonalia sp. (Brodbeck and Andersen, 2006; Brodbeck et al., 2006). The objective of this study was to determine the presence of these and other potential vectors of Xylella fastidiosa in coffee plantings in Puerto Rico.

\section{MATERIALS AND METHODS}

Study sites

This study was conducted on four coffee farms, all cultivated under the shaded system, in three different municipalities of the southern and central areas of Puerto Rico. Farms surveyed included Villa Cecilia on Route 372 in Yauco (latitude $18^{\circ} 08^{\prime} 1.2^{\prime \prime} \mathrm{N}$ and longitude $66^{\circ} 50^{\prime} 2.7^{\prime \prime} \mathrm{W}, 795-\mathrm{m}$ altitude). On this farm, coffee plants cv. Caturra were approximately 10 to 12 years old, and chemical control practices were used for production (application of aldicarb for insect control, and glyphosate for grass control). The majority of herbaceous weeds were the gramineous Paspalum virgatum L. ('cortadera') and Eleusine indica (L.) Gaertn ('pata de gallina'). One species of the Commelinaceae family, Commelina diffusa Burm. f. ('cohítre'), was found. Another farm sampled was Sierra Alta, located on Route 375 in Yauco (latitude $18^{\circ} 06^{\prime} 13.4^{\prime \prime} \mathrm{N}$ and longitude $66^{\circ} 49^{\prime} 42.7^{\prime \prime} \mathrm{W}$, 412-m altitude). On this farm coffee plants cv. Borbon were approximately 15 years old. No chemical or organic pesticide was used. The herbaceous vegetation was composed of species in the Cucurbitaceae family such as Momordica charantia L. ('cundeamor'), and in the Commelinaceae family, Commelina diffusa Burm. f. The third farm is located on Route 375 in Juana Díaz (latitude $18^{\circ} 8^{\prime} 37.4$ ” $\mathrm{N}$ and longitude $66^{\circ} 51^{\prime} 19.4^{\prime \prime} \mathrm{W}, 495-\mathrm{m}$ altitude). The cultivar of coffee on this farm was 15-year-old Borbon. As on the Sierra Alta farm, no chemical control was used. Herbaceous weeds were comprised of species in the families Commelinaceae (Commelina diffusa Burm. f.), Asclepidiaceae (Asclepias curassauca L.) ('algodoncillo') and Cucurbitaceae (Momordica charantia L.). The last farm is located on Route 526 in 
Adjuntas (latitude $18^{\circ} 13^{\prime} 12.1^{\prime \prime} \mathrm{N}$ and longitude $66^{\circ} 45^{\prime} 55.6^{\prime \prime} \mathrm{W}, 637-\mathrm{m}$ altitude). On this farm coffee trees cv. Limaní were approximately 12 to 15 years old; plants were treated with the insecticide aldicarb. There were a few herbaceous weeds associated with the coffee plants. Present on this farm were only two species of gramineous plants, Eleusine indica and Digitaria sanguinalis (L.) Scop ('pendejuelo', 'pata de gallina fina'), and one species in the Commelinaceae family (Commelina diffusa).

\section{Sampling methods}

Insects were collected by using yellow sticky trap cards measuring 8.5 $\times 11.5 \mathrm{~cm}$ and coated with Tanglefoot $\odot$ (Insect trap coating, Tanglefoot Company $)^{8}$. Fifteen traps were distributed $(40 \times 40 \mathrm{~m})$ in each coffee grove, hung at $1.5 \mathrm{~m}$ from branches of the coffee trees. Traps were replaced every 15 days from June to November 2006 for a total of 12 evaluations. Insect sweep nets were also used to sample leafhoppers in the herbaceous weeds inside the groves. For this collection method, we took five samples each month. Each sample was composed of 30 sweeps at five points randomly selected within each farm (the size of the sample for each sampling was that of 150 sweeps). Each farm was sampled six times.

\section{Insect identification}

The insects were removed from the traps by using $95 \%$ ethyl alcohol; some individuals of each genus were pin-mounted for collection purposes. The initial identification of all collected species was performed by Stuart McKamey (USDA) at the Smithsonian Institute in Washington, D.C., USA. All potential Xf vectors (Cicadellinae and Cecropidae) were identified to species, and all other Hemiptera identified to family using external morphological characters of adults. After preliminary identification of each species, identification of remaining collected specimens was conducted by comparison of type specimens to other collected insects by microscopic examination of morphological traits, as outlined by Borror's dichotomous key (Triplehorn and Johnson, 2005), and keys to the Cicadellinae defined by Young (1977). Collections used for comparison purposes belong to the University of Puerto Rico and were located at the Museum of Entomology and Tropical Biodiversity at the Agricultural Experiment Station in Río Piedras (Dr. Silverio Medina-Gaud), and at the Biology Department, UPR-Mayagüez (Dr. Nico Franz).

\footnotetext{
${ }^{8}$ Trade and company names in this publication are used only to provide specific information. Mention of a trade name does not constitute a warranty of equipment or materials by the Agricultural Experiment Station of the University of Puerto Rico, nor is this mention a statement of preference over other equipment or materials.
} 


\section{Faunistic analysis}

For statistical analysis of the community of Hemiptera, the following indexes were estimated: constancy, frequency, abundance and dominance. Those species that ranked higher with the above indexes were determined as the dominant species on each farm (Silveira Neto et al., 1976). Also determined were indexes of alpha ( $\alpha$ ) diversity: ShannonWiener $\mathrm{H}$ (used to compare diversity of hoppers in Puerto Rico with that in other neotropical countries), equitability $\mathrm{J}$ (Simpson); and dominance $\mathrm{D}$, beta ( $\beta$ ) diversity: index Bray-Curtis (=Sørensen quantitative) (Moreno, 2001). For calculating indexes of constancy, frequency and abundance, the dates were transformed by using natural logarithms, and all confidence intervals (CI) were calculated by using the statistical package INFOSTAT (Infostat, 2006).

The constancy index (COI), calculated in percentage, was obtained through the quotient between the number of collections of each species multiplied by 100 , and by the total number of collections performed (Silveira-Neto et al., 1976). Classes established with these indexes were divided as follows: constant $(\mathrm{W})=$ the occurrence percentage when a species was 50 to $100 \%$; accessory $(\mathrm{Y})=$ the occurrence when percentage for species was 25 to $50 \%$, and accidental $(\mathrm{Z})=$ the occurrence when percentage for species was less than $25 \%$ (Silveira-Neto et al., 1976).

Frequency is the percentage of the number of individuals for each species in relation to the total number of individuals of all species collected (Silveira-Neto et al., 1976). The frequency was calculated by using CI of an average of 5\% probability following Fazolin's distribution (Fazolin, 1991). Frequency was divided into the following classes: very frequent $(\mathrm{VF})=$ the percentage when the number of individuals of the species was greater than upper limit of CI at $5 \%$ probability; frequent $(F)=$ the percentage when the number of individuals caught for species was within the $\mathrm{CI}$ at $5 \%$ probability; and somewhat frequent $(\mathrm{FF})=$ the percentage when individuals caught for each species were fewer than the lower limit of $\mathrm{CI}$ at $5 \%$ probability.

Abundance refers to the number of individuals per unit area and varies for space and time (Silveira-Neto et al., 1976). The abundance was calculated by using the confidence intervals of $1 \%$ and $5 \%$ probability. The species were distributed into these classes: very abundant (va) = when the number of caught individuals was larger than the upper limit of CI at $1 \%$ probability; abundant (a) = when the number of caught individuals was within the upper limits of the CI at $5 \%$ and at $1 \%$ probability; common $(\mathrm{c})=$ when the number of caught individuals was located inside the CI at $5 \%$ probability; dispersed (di) $=$ when the number of caught individuals was located within the lower limits of the 
$\mathrm{CI}$ at $5 \%$ and at $1 \%$ probability; and rare $(\mathrm{r})=$ when the number of caught individuals was smaller than the lower limit of the CI at $1 \%$ probability.

The dominance index for each species was calculated with the method of Kato et al. (1952; cited by Laroca and Mielke, 1975). Species were divided according to the following limits:

Upper limit (UL): $\frac{n_{1} F_{0}}{n_{2}+n_{1} F_{0}}$

Where $n_{1}=2(k+1)$ and $n_{2}=2(N-k+1)$

Lower Limit (LL): $1-\left[\frac{n_{1} F_{0}}{n_{2}+n_{1} F_{0}}\right]$

Where $n_{1}=2(N-k+1)$ and $n_{2}=2(k+1)$

$N=$ Total number of individuals collected.

$k=$ Number of individuals of each species.

$F_{o}=$ value of $F$ distribution, degree of freedom (df) of $n_{1}$ and $n_{2}(\mathrm{p}=0.05)$.

Dominant species were those with an upper limit higher than lower limit for $k=0$.

The alpha $(\alpha)$ biodiversity indexes (Shannon-Wiener and Equitability) were calculated by using the statistical software PAST (Hammer, 2002) based on the followings equations:

Shannon-Wiener index: $H=-\sum \frac{n_{i}}{N_{i}} \ln \left[\frac{n_{i}}{N}\right]$

where $n_{i}=$ number of individuals in species $i$, and $N=$ total number of all individuals.

Equitability index: $J=\frac{H}{H_{\max }}=\frac{H}{\ln \mathrm{S}}$

where: $H$ = diversity of species observed and $H_{\max }=$ maximum diversity of species $=\operatorname{lnS}$ (species richness) $=$ Logarithm of number of taxa.

Dominance index: $D=\sum\left(\frac{n_{i}}{N}\right)^{2}$ 
Finally, for beta $(\beta)$ diversity index the Bray-Curtis (=Sørensen quantitative) was calculated by the statistical software Estimates (Colwell, 2005), based on the following equation:

$$
C_{N}=\frac{2 \mathrm{~J}_{N}}{a N+b N}
$$

Where $\mathrm{J}_{N}$ is sum of the lower abundances of each species shared by both sites, when comparing two habitats, $N$ is the total number of individuals of each species, $a$ is the number of species found in one habitat and $b$ is the number of species found in the other habitat.

\section{RESULTS AND DISCUSSION}

\section{Description of Communities}

Over 7,423 Hemiptera: Auchenorrhyncha were collected. On two farms, the density of Hemiptera varied greatly according to the month of sampling. For the farms of Adjuntas and Juana Díaz, the higher densities of individuals were found during the summer months (June and July) (Figures 1A and 1B). The highest hopper abundance was at Ad-
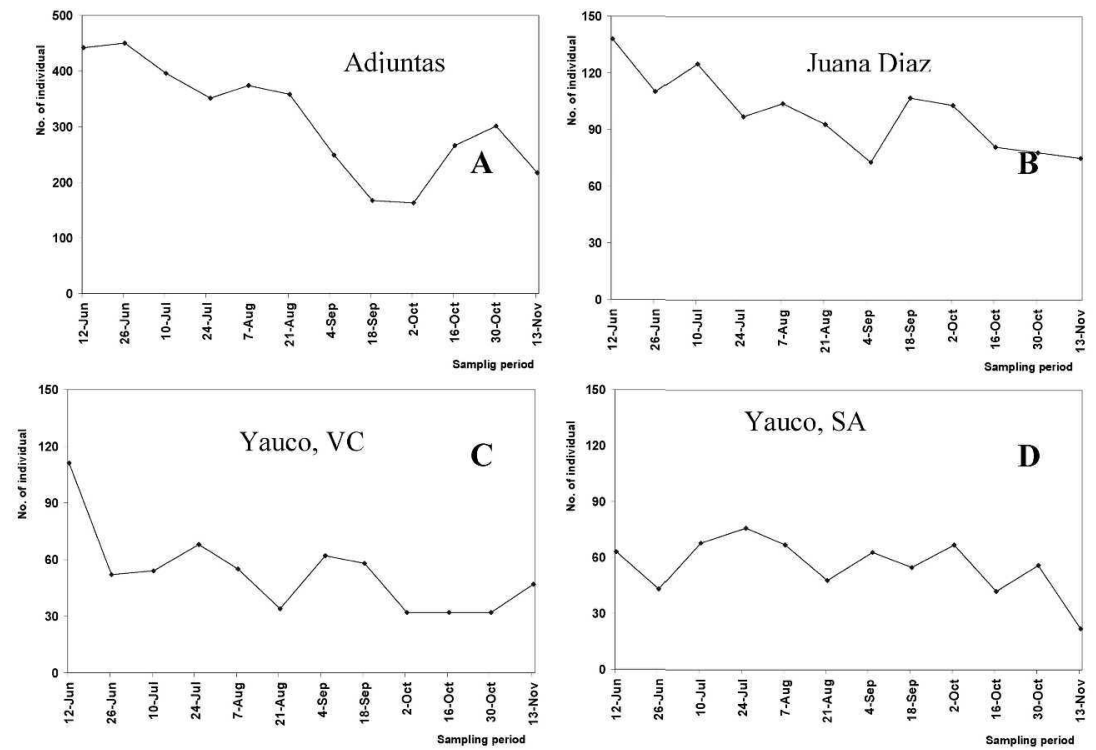

FIGURE 1. Densities of Auchenorrhyncha collected from four coffee farms of Puerto Rico from June to November 2006. Adjuntas (A); Juana Díaz (B); Villa Cecilia (C); and Sierra Alta (D). 
TABLE 1. Indexes of dominance, abundance, frequency and constancy of insects collected from four coffee farms in Puerto Rico, from June to November 2006.

\begin{tabular}{|c|c|c|c|c|c|c|c|}
\hline Farm & Family & Species & Total $^{1}$ & $\mathrm{D}^{2}$ & $\mathrm{~A}^{3}$ & $\mathrm{~F}^{4}$ & $\mathrm{C}^{5}$ \\
\hline \multirow[t]{15}{*}{ Adjuntas } & Cicadellidae & & & & & & \\
\hline & & Caribovia coffeacola & 4,465 & SD & VA & VF & $\mathbf{W}$ \\
\hline & & Hortensia similis & 17 & $\mathrm{D}$ & $\mathrm{R}$ & $\mathrm{FF}$ & $\mathrm{Z}$ \\
\hline & & Agalliopsis pepino & 55 & $\mathrm{D}$ & $\mathrm{R}$ & $\mathrm{FF}$ & Z \\
\hline & & Agallia pulchra & 162 & $\mathrm{D}$ & D & $\mathbf{F}$ & $\mathbf{Y}$ \\
\hline & & Scaphytopius neloricatus & 4 & $\mathrm{ND}$ & $\mathrm{R}$ & $\mathrm{FF}$ & $\mathrm{Z}$ \\
\hline & & Cicadellidae sp1 & 26 & $\mathrm{D}$ & $\mathrm{R}$ & $\mathrm{PF}$ & Z \\
\hline & Membracidae & & & & & & \\
\hline & & Nesshorinus gibberulus Stål & 26 & $\mathrm{D}$ & $\mathrm{R}$ & $\mathrm{PF}$ & Z \\
\hline & Achilidae & & & & & & \\
\hline & & Achilidae sp1 & 18 & $\mathrm{D}$ & $\mathrm{R}$ & $\mathrm{PF}$ & $\mathrm{Z}$ \\
\hline & Cixiidae & & & & & & \\
\hline & & Bothriocera sp. & 155 & $\mathrm{D}$ & C & $\mathbf{F}$ & $\mathbf{Y}$ \\
\hline & Tropiduchidae & & & & & & \\
\hline & & Tropiduchidae sp1 & 3 & $\mathrm{ND}$ & $\mathrm{R}$ & $\mathrm{PF}$ & Z \\
\hline \multirow[t]{3}{*}{ Juana Díaz } & Cicadellidae & & & & & & $\mathbf{W}$ \\
\hline & & Caribovia coffeacola & 899 & SD & VA & VF & $\mathbf{Z}$ \\
\hline & & Hortensia similis & 17 & $\mathrm{D}$ & $\mathrm{R}$ & $\mathrm{FF}$ & $\mathrm{Z}$ \\
\hline
\end{tabular}

Letters in highlight represent the predominant species throughout the faunistic indexes.

1Total of individuals: collected in the 12 samplings.

${ }^{2}$ Dominance - SD: super dominant; D: dominant; ND: non dominant.

${ }^{3} \mathrm{Abundance}-\mathrm{VA}$ : very abundant; $\mathrm{A}=$ abundant; $\mathrm{C}=$ common; $\mathrm{D}=$ disperse, and $\mathrm{R}=$ rare.

${ }^{4}$ Frequency - VF: very frequent; F: frequent; FF: Few frequent.

${ }^{5}$ Constancy - W: constant; Y: Accessory; Z: Accidental. 
TABLE 1. (CONTINUED) Indexes of dominance, abundance, frequency and constancy of insects collected from four coffee farms in Puerto Rico, from June to November 2006

\begin{tabular}{|c|c|c|c|c|c|c|c|}
\hline Farm & Family & Species & Total $^{1}$ & $\mathrm{D}^{2}$ & $\mathrm{~A}^{3}$ & $\mathrm{~F}^{4}$ & $\mathrm{C}^{5}$ \\
\hline & & Apogonalia imitatrix & 34 & $\mathrm{D}$ & $\mathrm{R}$ & $\mathrm{FF}$ & Z \\
\hline & & Agallia pulchra & 39 & $\mathrm{D}$ & $\mathrm{R}$ & $\mathrm{FF}$ & $\mathrm{Z}$ \\
\hline & & Scaphytopius neloricatus & 18 & $\mathrm{D}$ & $\mathrm{R}$ & $\mathrm{FF}$ & $\mathrm{Z}$ \\
\hline & & Cicadellidae sp1 & 3 & ND & $\mathrm{R}$ & $\mathrm{FF}$ & $\mathrm{Z}$ \\
\hline & & Cicadellidae sp2 & 6 & $\mathrm{D}$ & $\mathrm{R}$ & $\mathrm{FF}$ & \\
\hline & Membracidae & & & & & & $\mathrm{Z}$ \\
\hline & & Nesshorinus gibberulus Stål & 3 & ND & $\mathrm{R}$ & $\mathrm{FF}$ & \\
\hline & Achilidae & & & & & & $\mathrm{Z}$ \\
\hline & & Achilidae sp1 & 11 & $\mathrm{D}$ & $\mathrm{R}$ & $\mathrm{FF}$ & \\
\hline & Cixiidae & & & & & & $\mathbf{Y}$ \\
\hline & & Bothriocera sp. & 148 & $\mathrm{SD}$ & $\mathrm{C}$ & $\mathbf{F}$ & $\mathrm{Z}$ \\
\hline & Tropiduchidae & Tropiduchidae sp1 & 7 & $\mathrm{D}$ & $\mathrm{R}$ & FF & \\
\hline \multirow[t]{8}{*}{ Villa Cecilia } & Cicadellidae & & & & & & \\
\hline & & Caribovia coffeacola & 301 & SD & VA & VF & w \\
\hline & & Hortensia similis & 20 & $\mathrm{D}$ & $\mathrm{D}$ & $\mathrm{FF}$ & Z \\
\hline & & Agalliopsis pepino & 43 & SD & $\mathbf{C}$ & $\mathbf{F}$ & $\mathbf{Y}$ \\
\hline & & Agallia pulchra & 152 & SD & VA & VF & $\mathbf{w}$ \\
\hline & & Scaphytopius neloricatus & 6 & $\mathrm{D}$ & $\mathrm{R}$ & $\mathrm{FF}$ & Z \\
\hline & & Cicadellidae sp1 & 11 & $\mathrm{D}$ & $\mathbf{C}$ & $\mathbf{F}$ & $\mathbf{Y}$ \\
\hline & & Cicadellidae sp2 & 4 & $\mathrm{ND}$ & $\mathrm{R}$ & $\mathrm{FF}$ & $\mathrm{Z}$ \\
\hline
\end{tabular}

Letters in highlight represent the predominant species throughout the faunistic indexes.

${ }^{1}$ Total of individuals: collected in the 12 samplings.

${ }^{2}$ Dominance - SD: super dominant; D: dominant; ND: non dominant.

${ }^{3} \mathrm{Abundance}$ - VA: very abundant; $\mathrm{A}=$ abundant; $\mathrm{C}=$ common; $\mathrm{D}=$ disperse, and $\mathrm{R}=$ rare.

${ }^{4}$ Frequency - VF: very frequent; F: frequent; FF: Few frequent.

${ }^{5}$ Constancy - W: constant; Y: Accessory; Z: Accidental. 
TABLE 1. (CONTINUED) Indexes of dominance, abundance, frequency and constancy of insects collected from four coffee farms in Puerto Rico, from June to November 2006.

\begin{tabular}{|c|c|c|c|c|c|c|c|}
\hline Farm & Family & Species & Total $^{1}$ & $\mathrm{D}^{2}$ & $\mathrm{~A}^{3}$ & $\mathrm{~F}^{4}$ & $\mathrm{C}^{5}$ \\
\hline & Membracidae & & & & & & \\
\hline & & Nesshorinus gibberulus Stål. & 4 & ND & $\mathbf{R}$ & FF & $\mathbf{Z}$ \\
\hline & Cixiidae & & & & & & \\
\hline & & Bothriocera sp. & 96 & $\mathrm{SD}$ & $\mathbf{C}$ & $\mathbf{F}$ & $\mathbf{Y}$ \\
\hline \multirow[t]{11}{*}{ Sierra Alta } & Cicadellidae & & & & & & \\
\hline & & Caribovia coffeacola & 11 & $\mathrm{D}$ & $\mathrm{R}$ & $\mathrm{FF}$ & $\mathrm{Z}$ \\
\hline & & Hortensia similis & 14 & $\mathrm{D}$ & $\mathrm{R}$ & $\mathrm{FF}$ & $\mathrm{Z}$ \\
\hline & & Apogonalia imitatrix & 320 & SD & VA & VF & $\mathbf{W}$ \\
\hline & & Agalliopsis pepino & 153 & SD & VA & VF & $\mathbf{W}$ \\
\hline & & Agallia pulchra & 16 & $\mathrm{D}$ & $\mathrm{R}$ & $\mathrm{FF}$ & $\mathrm{Z}$ \\
\hline & & Scaphytopius neloricatus & 14 & $\mathrm{D}$ & $\mathrm{R}$ & $\mathrm{FF}$ & Z \\
\hline & Achilidae & & & & & & \\
\hline & & Achilidae sp1 & 1 & ND & $\mathrm{R}$ & $\mathrm{FF}$ & Z \\
\hline & Cixiidae & & & & & & \\
\hline & & Bothriocera sp. & 141 & SD & VA & VF & $\mathbf{W}$ \\
\hline
\end{tabular}

Letters in highlight represent the predominant species throughout the faunistic indexes.

'Total of individuals: collected in the 12 samplings.

2Dominance - SD: super dominant; D: dominant; ND: non dominant.

${ }^{3}$ Abundance - VA: very abundant; $\mathrm{A}=$ abundant; $\mathrm{C}=$ common; $\mathrm{D}=$ disperse, and $\mathrm{R}=$ rare.

${ }^{4}$ Frequency - VF: very frequent; F: frequent; FF: Few frequent.

${ }^{5}$ Constancy - W: constant; Y: Accessory; Z: Accidental. 
juntas even though pesticides were used at that farm. For Puerto Rico, these results were similar to those of Brodbeck et al. (2006). Similar results were observed by Olszewski (1996) in New Jersey for new potential vectors of $X$. fastidiosa. The distribution of individuals did not significantly change during sampling at the other two farms in Yauco (Villa Cecilia and Sierra Alta) (Figures 1C and 1D).

In general, the community of Auchenorrhyncha at all sampling sites were represented by five families and 12 species: Cicadellidae (6,810 individuals and eight species); Cixiidae (540 and 1); Membracidae (33 and 1); Achilidae (30 and 1); and Tropiduchidae (10 and 1). At all sites Cicadellidae was the most common family in terms of both numbers of both species $(66.67 \%)$ and individuals $(91.72 \%)$ (Figure 2). These results are similar to those reported in studies conducted in coffee and citrus groves in Costa Rica (Rojas et al., 2001; Garita et al., 2006; Godoy et al., 2005) and in coffee (Menequim et al., 2001) and citrus plantations in Brazil (Yamamoto and Gravena, 2000; Marucci et al., 2002; Yamamoto et al., 2002; Pedreida, 2003). When the family composition of each farm is compared, some differences are observed. Only for the two farms at Adjuntas and Juana

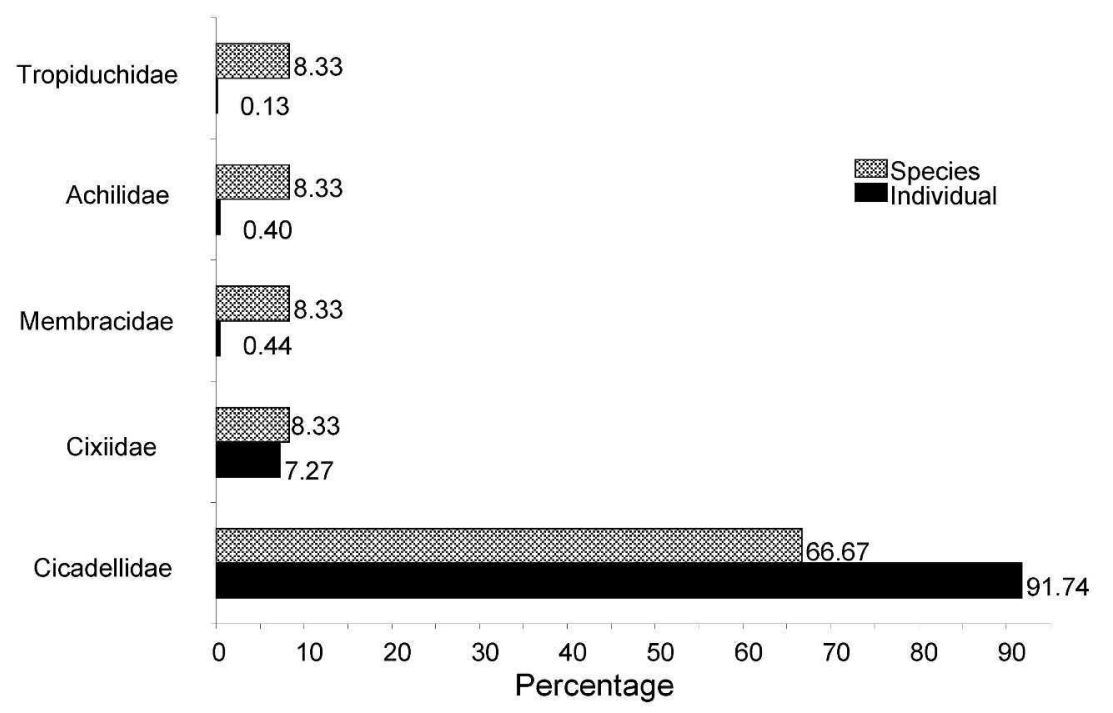

FIGURE 2. Relative frequency of families and species (Hemiptera: Auchenorrhyncha) collected on four coffee farms of Puerto Rico from June to November 2006. $n_{1}=$ Total number of individuals was 7,423 , representing 12 species. 
Díaz were the species distributed among the five families. On the other two farms (Villa Cecilia and Sierra Alta) the species were distributed among three of the five families. Cicadellidae and Cixiidae were common at all sites (Table 1).

\section{Faunistic analysis}

According to the higher values of dominance (SD), abundance (va), frequency (VF) and constancy (W) indexes, the species Caribovia coffeacola was dominant on three of the four farms (Adjuntas, Juana Díaz and Villa Cecilia). The species Apogonalia imitatrix Young and Agalliopsis pepino were dominant at Sierra Alta, and the species Agallia pulchra was predominant at Villa Cecilia (Table 1). This distribution indicates that these species were present on the farms throughout all sampling dates and probably fed directly on the coffee plants, although we cannot rule out weeds as hosts. Similar results have been previously reported in Puerto Rico for C. coffeacola (Brodbeck and Andersen, 2006; Brodbeck et al., 2006) and for species of Agallia in Brazil (Hickel et al., 2001; Yamamoto and Gravena, 2000).

\section{Biodiversity indexes}

Table 2 shows the values of diversity index Shannon-Weiner $(\mathrm{H})$, equitability $(\mathrm{J})$ and dominance (D). Significant differences were detected among locations $(\mathrm{P}<0.005)$, with higher values of $\mathrm{H}$ and $\mathrm{J}$ and lower values of D observed on the farms in Yauco. Diversity $(\mathrm{H})$ obtained in our study ranged from 0.37 to 1.14 (Table 2). According to these values, it can be concluded that in our study the Auchenorrhyncha communities are less diverse in Puerto Rico than in other neotropical countries such as Costa Rica ( $\mathrm{H}=2.56$ to 2.84 ) (Rojas et

TABLE 2. Total of individuals, richness, diversity, equitability and dominance indexes of insects (Hemiptera: Auchenorrhyncha) collected from four coffee farms in Puerto Rico, from June to November 2006.

\begin{tabular}{lccccc}
\hline Farms & $\begin{array}{c}\text { Total } \\
\text { individuals }\end{array}$ & Richness & $\begin{array}{c}\text { Diversity } \\
\text { Shannon- } \\
\text { Wiener }(\mathrm{H})\end{array}$ & $\begin{array}{c}\text { Equitability } \\
(\mathrm{J})\end{array}$ & $\begin{array}{c}\text { Dominance } \\
(\mathrm{D})\end{array}$ \\
\hline Adjuntas & 4,931 & 10 & $0.37 \mathrm{a}$ & $0.23 \mathrm{a}$ & $\mathbf{0 . 8 4} \mathbf{c}$ \\
Juana Díaz & 1,185 & 11 & $0.86 \mathbf{b}$ & $0.45 \mathrm{~b}$ & $0.61 \mathrm{~b}$ \\
Villa Cecilia & 637 & 9 & $\mathbf{1 . 1 1} \mathbf{c}$ & $\mathbf{0 . 7 5} \mathbf{c}$ & $0.39 \mathrm{a}$ \\
Sierra Alta & 670 & 8 & $\mathbf{1 . 1 4} \mathbf{c}$ & $\mathbf{0 . 7 7} \mathbf{c}$ & $0.39 \mathbf{~ a}$ \\
\hline
\end{tabular}

Different letters indicate significant differences $(p<0.05)$. 
al., 2001) and in two studies from Brazil ( $\mathrm{H}=1.69$ to 2.31) (Pedreida, 2003 ); ( $\mathrm{H}=1.10$ to 2.44 ) (Ott and Caravalho, 2001). The lower diversity found in this study is probably due to the greater prevalence of the subfamily Cicadellinae or to the insular nature of Puerto Rico. Islands are typically less diverse than the neighboring mainlands. In Puerto Rico, 138 cicadellid species have been recorded, whereas there are 1,567 species in Brazil and 383 species in Costa Rica (McKamey, 2007). Particularly low values of equitability and dominance were observed in Adjuntas and Juana Díaz. This finding is probably due to the presence of dominant species (Pedreida, 2003). In our case only one species, Caribovia coffeacola, was responsible; this number represented $75.9 \%$ of insects trapped in Juana Díaz, and $95.8 \%$ of those in Adjuntas.

Species composition was most similar between the Juana Díaz and Villa Cecilia (Yauco) farms, with Bray-Curtis value (0.515) (Table 3). This result indicates that on these farms there are a greater number of common species equivalent in abundance (Moreno, 2001). However, species composition for the four farms was similar. Only a few species were not present at all places; for example, Apogonalia imitatrix Young was present only at Sierra Alta in Yauco and at Juana Díaz. This species was identified by S. McKamey and represents the first report for Puerto Rico. Agalliopsis pepino was collected at Adjuntas and Sierra Alta. The absence of these species in other samples may have been due to a low diversity of weeds present on these farms since herbaceous vegetation is an important factor that favors the coexistence of different species of leafhoppers (Pedreida, 2003).

\section{Potential Xf Vectors}

The majority of Auchenorrhyncha collected in this study were Cicadellidae (Table 2). The Cicadellidae are comprised of almost 40 subfamilies which feed on phloem fluid and a variety of other plant tissue (Neilsen, 1985). Only the subfamily Cicadellinae feed on xylem fluid and thus potentially vector Xf (Hopkins, 1977; Purcell, 1989; Redak et

TABLE 3. $\beta$ Biodiversity index of insects (Hemiptera: Auchenorrhyncha) of four coffee farms in Puerto Rico, from June to November 2006.

\begin{tabular}{lc}
\hline Combinations & Similarity (Bray-Curtis) \\
\hline Adjuntas-Juana Díaz & 0.369 \\
Adjuntas-Villa Cecilia & 0.226 \\
Adjuntas-Sierra Alta & 0.086 \\
Juana Diaz-Villa Cecilia & $\mathbf{0 . 5 1 5}$ \\
Juana Diaz-Sierra Alta & 0.237 \\
Villa Cecilia-Sierra Alta & 0.279 \\
\hline
\end{tabular}


al., 2004). Acquisition of Xf occurs after the stylet sheaths of Cicadellinae penetrate xylem vessels of infected plants and ingest xylem fluid (Backus et al., 2009). The bacteria enters the stylet sheath and resides in the foregut until the vector accesses another xylem vessel, at which time the pathogen will be introduced into the new xylem vessel (Alves et al., 2008). Unlike many pathogens vectored by insects, $\mathrm{Xf}$ is non-circulative and does not pass into the digestive system, where bacterial growth and incubation often occur in other types of vectors. Thus, $\mathrm{Xf}$ acquisition and transmission can occur with exceedingly brief feeding bouts. All Cicadellinae are thus potential vectors of Xf, although transmission efficiencies have been shown to vary somewhat with vector species (Redak et al., 2004).

Although Cicadellinae are only one subfamily of Cicadellidae, our analysis shows that Cicadellinae are often the dominant leafhoppers collected in coffee plantings. Caribovia coffeacola (Figure 3) was the dominant species at Adjuntas, Juana Díaz and Villa Cecilia. Another Cicadellinae, Apogonalia imitatrix, was one of the two dominant species at Sierra Alta. The other two dominant species, A. pulchra and A. pepino, belong to subfamily Agalliinae, and the majority of species are phloem-feeding insects (Brodbeck et al., 2006). Species of this genus have been reported as virus vectors of other diseases of economic importance (Coll et al., 1998). The overall frequency and diversity of Auchenorrhyncha appear low compared to similar studies conducted in Central and South America (Rojas et al., 2001; Pedreida, 2003). However, the capacity of these insect communities to vector Xf may be high, given the dominance and frequency of Cicadellinae species.

Hortensia similis (Figure 3) was another Cicadellinae present in our study and has been reported to vector $\mathrm{Xf}$ in other locations (Mizell et al., 2003; Purcell, 2005; Redak et al., 2004). This species was classified in our indexes as infrequent (FF), accidental (Z), rare (r) and dominant (D). A similar distribution has been noted by other researchers (Beltrán et al., 2004; Yamamoto et al., 2002; Pedreida, 2003). However, $H$. similis was observed as dominant in the collections obtained with sweep net on the herbaceous weeds (C. diffusa, P. virgatum, E. indica) inside the groves. These findings are similar to those of Yamamoto and Gravena (2000) and Marucci et al. (2002). Hortensia similis feeds primarily on grass and only occasionally on hardwoods (Brodbeck and Andersen, 2006). This behavior was also reported by Ott et al. (2006) when they were evaluating the presence of leafhoppers on herbaceous weeds inside groves. In our study this species was reported as constant. The abundance and polyphagy of $H$. similis may represent a serious problem in areas that currently harbor asymptomatic hosts of Xf. Lopes et al. (2003) found that Xf can be present in asymptomatic 


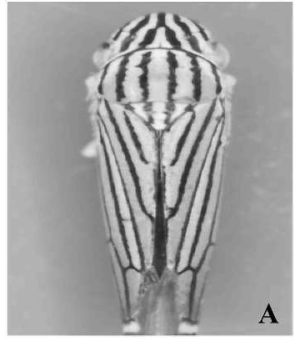

Caribovia coffeacola ( 7 to $9 \mathrm{~mm})$

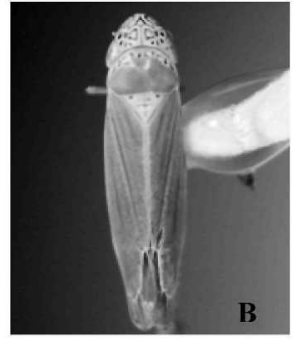

Hortensia similis (6 to $7 \mathrm{~mm}$ )

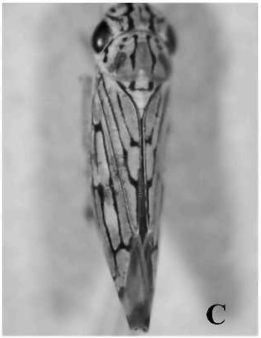

Apogonalia imitatrix (5 to $6 \mathrm{~mm}$ )

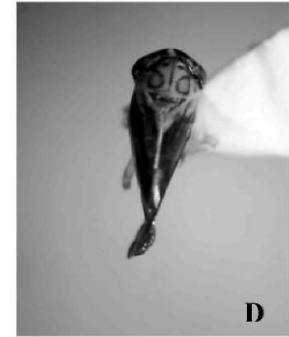

Agalliopsis pepino (2 to $3 \mathrm{~mm})$

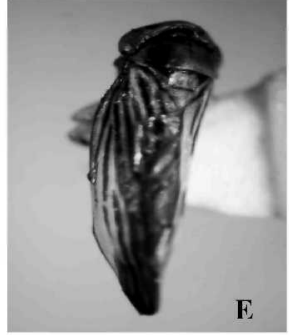

Agallia pulchra (3 to $4 \mathrm{~mm})$

FIGURE 3. Dominant insect species (Hemiptera: Auchenorrhyncha: Cicadellidae) on four coffee farms in Puerto Rico. Species A, B, and C potential vectors of X. fastidiosa; D and $\mathrm{E}$ are mainly vectors of virus.

weeds. These weeds could be a primary source for the acquisition of Xf for sharpshooters that feed off them, with potential dissemination into plants of economic importance.

Abundances of Cicadellinae mirrored abundances of all Hemiptera in that densities were highest during summer and were highest at the inland mountainous site at Adjuntas. Our diversity of sites and sampling throughout the year provided a range of abiotic conditions. Cicadellinae distribution may be impacted by temperature, precipitation, photoperiod, humidity or biotic (natural enemies) conditions, but the determination of specific factors influencing Cicadellinae populations was beyond the scope of this study. We note, however, that a characteristic of many Cicadellinae species is high polyphagy (Mizell and French, 1987, Brodbeck et al., 1990; Redak et al., 2004). A wide diversity of alternative host species was present in the forests surrounding coffee plantings in Adjuntas. Similarly, weedy alternative hosts within coffee plantings flourished during the summer rainy season, when Cicadellinae populations were highest. Hortensia similis has been shown 
to thrive on such weedy hosts (Yamamoto and Gravena, 2000; Marucci et al., 2002). Differences in the abundance of Apogonalia imitatrix on the two farms in Yauco may also be related to alternative host plants. The close proximity of the farms suggests that abiotic conditions would be similar. However, cultural practices were different with no weed control at Sierra Alta, where populations of Apogonalia were higher. Previous studies have also suggested that the most important factor determining leafhopper distribution may be the diversity and number of alternative hosts as many leafhoppers are highly polyphagous and may utilize these alternative food sources (Paiva et al., 1996).

Apogonalia imitatrix, C. coffeacola and $H$. similis are the primary potential vectors of Xf in Puerto Rico. A more serious threat to coffee plantations may be C. coffeacola because of its abundance and presence on all farms. This species was also most commonly collected directly on coffee, whereas Apogonolia was collected on a wide variety of species, mainly on Momordica charantia L.; and $H$. similis was most commonly collected on grasses. Future works should focus on feeding preferences within both coffee and alternative host plants, determining the abundance in different seasons and the presence of Xf in these three species in order to quantify their potential impact as Xf vectors.

\section{LITERATURE CITED}

Almeida, R. P. and A. H. Purcell, 2003. Transmission of Xylella fastidiosa to grapevines by Homalodisca coagulata (Hemiptera: Cicadellidae). J. Econ. Entomol. 96(2):264271.

Alves E., B. Leite, R. C. Marucci, S. F. Pascholati, J. R. S. Lopes and P. C. Andersen, 2008. Retention sites for Xylella fastidiosa in four sharpshooter vectors (Hemiptera: Cicadellidae) analyzed by scanning microscopy. Current Microbiology 56:531-538.

Backus, E. A, W. J. Holmes, F. Schreiber, B. J. Reardon and G. P. Walker, 2009. Sharpshooter X Wave: Correlation of an electrical penetration graph waveform with $\mathrm{xy}$ lem penetration supports a hypothesized mechanism for Xylella fastidiosa inoculation. Annals of the Ent. Soc. 102:847-867.

Blake, B., T. Shu-Jen, H. Shaikh, M. Blua and T. A. Millar, 2004. Evaluation of methods for extracting Xylella fastidiosa DNA from the Glassy-Winged Sharshooter. J. Econ. Entomol. 97(3):757-763.

Brodbeck, B. V., R. F. Mizell III, W. J. French, P. C. Andersen and J. H. Aldrich, 1990. Amino acids as determinants of host preference for the xylem feeding leafhopper, Homalodisca coagulata (Hemiptera: Cicadellidae). Oecologia 83:338-345.

Brodbeck, B. and P. Andersen, 2006. Status of Xylem Limited Bacterium Xylella fastidiosa in Puerto Rico. North Florida Research and Education Center, University of Florida. NFREC NEWS 8(19):3 p.

Brodbeck, P., M. Zapata, S. Oden, Y. Mariño and P. Andersen, 2006. Potential leafhoppers vectors of Xylella fastidiosa in Puerto Rico. Proceedings Caribbean Food Crops Society. San Juan Puerto Rico, July 9 to 15.74 p.

Colwell, R., 2005. Estimates: statistical estimation of species richness and shared species from samples. Versión 7.5. Department of Ecology and Evolutionary Biology, University of Connecticut, U.S.A. <http://viceroy.eeb.uconn.edu/estimateS>. 
Coll, O., A. Renes, J. Agostini and S. Paradell, 1998. Aspectos generales de la clorosis variegada de los cítricos (CVC) en Misiones. Citrumisiones 27:1-11.

Fazolin, M., 1991. Análise faunística de insetos coletados com armadilha luminosa em seringueira no Acre. Tese de doutorado, Universidade de São Paulo, SP, Brasil, $236 \mathrm{p}$.

Garita, J., C. Godoy, W. Villalobos and C. Rivera, 2006. Leafhoppers (Hemiptera: Cicadellidae) as potencial vectors of Xylella fastidiosa in Costa Rica. Phytopathol. 96(6):S142.

Godoy, C., J. Garita, W. Villalobos and C. Rivera, 2005. Diversity of Cicadellidae (Hemiptera: Auchenorryncha: Membracoidea) and potencial vectors of Xylella fastidiosa in coffee plants. Memories of 12th International Auchenorrhyncha Congress. University of California, Berkeley.

Hammer, O., 2002. Paleontological community and diversity analysis (PAST)- brief notes. Zürich, June 3.

Hickel, E., J. Ducroquet, R. P. Leite and R. M. Leite, 2001. Fauna de Homoptera: Auchenorrhyncha em pomares de Ameixeira em Santa Catarina. Neotropical Entomology 30(4):725-729.

Hopkins, L., 1977. Disease caused by leafhopper-borne rickettsia-like bacteria. Ann. Rev. Phytopathol. 17:277- 294.

Hopkins, L., 1989. Xylella fastidiosa: xylem-limited bacterial pathogens of plants. Ann. Rev. Phytopathol. 27:271-290.

Infostat, 2006. Infostat, version 2006. Manual del Usuario. Grupo Infostat, FCA, Universidad Nacional de Córdoba. Primera Edición. Editorial Brujas. Córdoba, Argentina.

Kato, M., T. Matsuda and Z. Yamashhita, 1952. Associative ecology of insects found in paddy field cultivated by various planting forms. Sci. Rep. Tohoku Univ. 19:291-301.

Laroca, S. and O. Mielke, 1975. Ensaios sobre ecologia de comunidade em Sphingidae na Serra Do Mar, Paraná, Brasil (Lepidoptera). Rev. Brasil. de Biol. 35(1):1-19.

Li, W., W. Pria, D. Texeira, V. Miranda, A. Franco, M. Costa, C. He, P. Costa and J. Hartung, 2001. Coffee leaf scorch caused by a strain of Xylella fastidiosa from citrus. Plant Dis. 85:501-505.

Lopes, S., S. Marcussi, Z. Torres, V. Souza, C. Fagan and C. França, 2003. Weeds as alternative host of the citrus, coffee, and plum strains of Xylella fastidiosa in Brazil. Plant Dis. 87(5):544-549.

Lopes, J., 1996. Mecanismos de transmissão of Xylella fastidiosa por cigarrinhas. Laranja 17(1):79-92.

McKamey, S. H., 2007. Taxonomic catalogue of the leafhoppers (Membracoidea). Part 1. Cicadellinae. Memoirs Amer. Entomol. Institute 78:1-394.

Marucci, R., R. Cavichioli and R. Zucchi, 2002. Espècies de cigarrinhas (Hemiptera, Cicadellidae, Cicadellinae) em pomares da região de Benedouro, SP, com descrição de uma espécie nova Acrogonia Stål. Rev. Bras. Entomol. 46(2):149-164.

Menequim, A., L. Akemi and R. Pedreida, 2001. Levantamento da fauna de homópteros vectores de Xylella fastidiosa em viveiros de mudas de cafeeiro (Coffea arabica L.). PROMECAFE, Boletin 91-92:23-24.

Mizell, R. F. M. and W. J. French, 1987. Leafhopper vectors of phony peach disease: feeding site preference on infected an uninfected peach, and seasonal response to selected host plants. J. Entomol Sci. 22:11-22.

Mizell, R., P. Andersen, C. Tipping and B. Brodbeck, 2003. Xylella fastidiosa diseases and their leafhopper vectors. University of Florida. Pp. 1-7.

Moreno, C., 2001. Métodos para medir la biodiversidad. SEA-Manuales y Tesis SEA vol. 1. Zaragoza, $84 \mathrm{p}$.

Monroig, M., 2007. Ecos del café. <http://academic.uprm.edu/mmonroig/>. August, 2007. 


\section{MARIÑO-CÁRDENAS ET AL./VECTORS OF XYLELLA FASTIDIOSA}

Newman, K., R. Almeida, A. Purcell and S. Lindow, 2004. Cell-cell signaling controls Xylella fastidiosa interactions with both insects and plants. Microbiology 101(5):1737-1742.

Nielson, M., 1985. Leafhoppers systematic. The Leafhoppers and Planthoppers. New York: John Wiley. Chapter 2. 11-39 p.

Olszewski, M., 1996. Identification of the possible vectors of Xylella fastidiosa, causal agent of oak leaf scorch. In: Memories of Bacterial leaf scorch of Amenity trees: A wide-spread problem of economic significance to the urban Forest. October 12, 2002. Rutgers University, New Brunswick, New Jersey. 8 p.

Ott, A., W. Azevedo, A. Ferran and G. Caravalho, 2006. Abundância e sazonabilidad de cigarrhinas (Hemiptera, Cicadellidae, Cicadellinae) en vegetação herbácea de pormar laranja doce, no municipio de Montenegro, Estado Rio Grande do Sul, Brasil. Iheringia, Sér. Zool., Porto Alegre 96(4):425-429.

Ott, A. and G. Carvalho, 2001. Comunidade de Cigarrinhas (Hemiptera: Auchenorrhyncha) de uma Área de campo do Município de Viamão, Rio Grande do Sul, Brasil. Neotropical Entomology 30(2):233-243.

Paiva, P., J. Da Silva, S. Gravena and P. Yamamoto, 1996. Cigarrinhas de xilema em pomares de laranja do estado de São Paulo. Laranja 17:41-54.

Pedreida, M., 2003. Levantamiento de cigarrinhas (Hemiptera: Cicadellidae) vetoras de Xylella fastidiosa em pomares de cítricos do litoral Norte da bahia. Tesis M.S. Escuela Superior de Agricultura. PIRACICABA. São Pablo, Brasil. 75 pp.

Purcell, A., 2005. A scientific and community internet resource on plant disease caused by the bacterium Xylella fastidiosa. <http:/www.cnr.berkeley.edu/xylella/>.

Purcell, A., 1994. Cigarrinhas na cultura de citros. In: Seminário Internacional de Citros, 3. Bebedouro. Campinas: Fundação Cargill. 195-209.

Purcell, A., 1989. Homopteran transmission of xylem-inhabiting bacteria. Adv. Dis. Vector Res. 6:243-266.

Purcell, A. and D. Hopkins, 1996. Fastidious xylem-limited bacterial plant pathogens. Ann. Rev. Phytopathol. (34):131-151.

Redak, R., A. Purcell, J. Lopes, M. Blua, R. Mizell and P. Andersen, 2004. The biology of xylem fluid-feeding insect vectors of Xylella fastidiosa and their relation to disease epidemiology. Ann. Rev. Entomol. 49:243-270.

Rojas, L., C. Godoy, P. Hanson and L. Hilje, 2001. A survey of homopteran species (Auchenorrhyncha) in coffee, poro and laurel in shaded coffee plantations, in Turrialba, Costa Rica. Revista de Biología Tropical 49(3):981-989.

Silveira-Neto, S., O. Nakano and N. Vila Nova, 1976. Manual de ecologia dos insetos. Piracicaba, Agronômica Ceres, $419 \mathrm{p}$.

Triplehorn, C. and N. Johnson, 2005. Introduction to the Study of Insects. Thomson Brooks, Australia. 7th edition. 268-332.

Wells, J., B. Raju, H. Hung, W. Weisburg, P. Mandelco and D. Brenner, 1987. Xylella fastidiosa gen. nov., sp. nov.: gram-negative, xylem-limited, fastidious plant bacteria related to Xanthomonas spp. Int. J. Syst. Bacteriol. 37:136-143.

Yamamoto, P. and S. Gravena, 2000. Leafhoppers and psyllids (Homoptera) species and abundance in citrus orchards. An. Soc. Entomol. Bras. 29(1):169-176.

Yamamoto, P., S. Roberto, W. Pria, M. Felippe and E. De Freitas, 2002. Species and population dynamics of sharpshooters in nursery citrus, located at Mogi-Guaçu, Sp. Rev. Bras. Furtic. 24(2):389-394.

Young, D. A., 1977. Taxonomic Study of the Cicadellinae (Homoptera: Cicadellidae). Part 2 New World Cicadellini and the genus Cicadella. Technical Bulletin of the North Carolina Agricultural Experiment Station 239:1-1135. (description).

Young, D. A., 1968. Taxonomic study of the Cicadellidae. United States National Museum. Washington. Bulletin 261. $287 \mathrm{p}$. 